\title{
TEORI-TEORI ETIKA DAN SUMBANGAN PEMIKIRAN PARA FILSUF BAGI ETIKA BISNIS
}

\author{
Urbanus Ura Weruin
}

Jurusan Akuntansi, Fakultas Ekonomi Universitas Tarumanagara Jakarta

Email: urbs.weruin@gmail.com

\begin{abstract}
ABSTRAK
Sebagai ilmu preskriptif, etika adalah cabang filsafat yang mempertimbangakan secara kritis tindakan mana yang baik atau tindakan mana yang buruk berdasarkan ajaran moral tertentu. Sementara ajaran moral adalah ajaran tentang kebaikan manusia berdasarkan martabat setiap orang sebagai manusia. Studi literer dengan menggunakan metode content analysis yang dilakukan terhadap berbagai sumber kepustakaan yang ada memperlihatkan bahwa terdapat dua teori utama etika yang relevan bagi etika bisnis. Pertama teori etika konsekuensialis atau teleologis. Kedua, teori etika nonkonsekuensilis Termasuk dalam teori etika konsekuensilis adalah etika utilitarianisme, etika egoism, dan etika hedonisme. Sementara teori etika non-konsekuensialis mencakup etika deontologi, etika keutamaan, dan etika kesetaraan dan keadilan sebagai kewajaran. Etika konsekuensialis menilai moralitas tindakan atau keputusan berdasarakan tujuan, kegunaan, atau dampak positif yang diperoleh dari tindakan atau keputusan tersebut. Sementara etika nonkonsekuensialis memfokuskan moralitas tidakan atau putusan pada kewajiban untuk melakukan apa yang merupakan kewajiban, pada motivasi dan karakter moral si pelaku tindakan, serta pada prinsip keadilan. Semua teori etika ini, berkontribusi bagi pemahaman terhadap etika bisnis.
\end{abstract}

Kata Kunci: konsekuensialis, non-konsekuensialis, utilitarianisme, deontologi.

\section{ABSTRACT}

As a prescriptive science, ethics is a branch of philosophy that considers critically which actions are good or which actions are bad based on certain moral teachings. While moral teachings are teachings about human kindness based on the dignity of each person as a human being. Literary studies using content analysis methods conducted on various sources of existing literature show that there are two main theories of ethics that are relevant for business ethics. First the consequentialist or teleological ethical theory. Second, the theory of non-consensual ethics Included in the theory of consequent ethical ethics is the ethics of utilitarianism, ethics of egoism, and ethics of hedonism. While non-consequentialist ethical theories include deontological ethics, virtue ethics, and equality and fairness ethics as fairness. Consequentialist ethics assesses the morality of an action or decision based on the purpose, usefulness, or positive impact obtained from the action or decision. While non-consequentialist ethics focuses on the morality of actions or decisions on the obligation to do what is mandatory, on the motivation and moral character of the perpetrators of actions, as well as on the principle of justice. All of these ethical theories, contribute to understanding business ethics.

Keywords : consequentialist, non-consequentialist, utilitarianism, deontology

\section{PENDAHULUAN}

Seiring dengan munculnya skandal-skandal bisnis tak etis yang menimpah perusahaanperusahaan nasional seperti, Lapindo Brantas, Bantuan Liquiditas Bank Indonesia (BLBI), Bill Out Bank Centuty, atau praktis bisnis tak etis yang dilakukan oleh petinggi perusahaan multinasional seperti tampak pada kasus Enron dan Arthur Anderson semakin menegaskan perlunya pemahaman komprehensif terhadap etika bisnis dan profesi dari berbagai disiplin termasuk dari perspektif filsafat. Di tanah air, tidak hanya bahwa kuliah etika bisnis dan profesi menjadi bagian dari kurikulum yang mesti dibekali kepada mahasiswa ekonomi melainkan juga menjamurnya buku-buku etika bisnis dan profesi dengan perspektif yang beragam. Buku Etika Bisnis dan Profesi, Tantangan Membangun Manusia Seutuhnya karya Soekrisno Agoes dan I 
Cenik Ardana (2011) misalnya membahas etika bisnis dan profesi akuntan dengan bertolak dari pemahaman terhadap hakikat manusia sebagai makhluk rasional, alamiah, spiritual, dan etis yang mampu membangun relasi yang harmonis antara individu, masyarakat, dan alam semesta. Dengan kerangka yang hampir mirip buku terjemahan Etika Bisnis dan Profesi untuk Direktur, Eksekutif, dan Akuntan karya Leonard J. Brooks dan Paul Dunn (2015) membahas etika bisnis dengan menggunakan pendekatan pragmatis-empiris. Pendekatan yang berbeda ditempuh oleh penulis buku Pengantar Etika Bisnis karya K. Bertens (2013) atau buku Etika Bisnis: Pendekatan Filsafat Moral terhadap Perilaku Pebisnis Kontemporer karya L. Sinuor Yosephus (2010). Dua buku yang disebutkan terakhir ini menggunakan pendekatan filsafati. Tepatnya, etika bisnis sebagai penerapan prinsip-prinsip etis dalam bisnis.

Pendekatan filsafati terhadap bisnis tentu bukan tanpa alasan. Banyak pemikir menunjukkan bahwa filsafat (baca: etika) seharusnya berkontribusi bagi pemahaman terhadap prinsip dan praktik bisnis. Richard T. De George dalam artikelnya, The Relevance of Philosophy to Business Ethics: A Response to Rorty's "Is Philosophy Relevant to Applied Ethics?"” (2015), sudah menunjukkan bahwa filsafat sekarang bukan merupakan sebuah disiplin akademik yang teknis, kaku, dan tidak memiliki kepentingan dan signifikansi bagi publik pada umumnya. Etika bisnis sebagai bagian dari metaetika dan etika terapan memberikan sumbangan positif berupa pertimbangan-pertimbangan moral aktual berhadapan dengan berbagai kebijakan dan praktik bisnis yang berlangsung.

Guna menegaskan relevansi filsafat bagi berbagai disiplin akademik dan bisnis, dalam artikel onlinenya, Four Reasons Why Philosophy Is As Relevant As Ever, Joanna Hughes (2018) menyatakan bahwa today is World Philosophy Day! (Hughes, 2018). Dalam kaitannya dengan bisnis, tidak hanya bahwa filsafat dan petimbangan nilai-moralnya masih tetap sama relevannya dengan era sebelumnya melainkan juga bahwa filsafat membantu kamu professional memiliki "soft skills" berupa kemampuan berpikir kritis, sistematis, konsisten, dan menyeluruh dalam memahami, menganalisis, dan menyaring berbagai informasi serta persoalan dan dengan demikian bertindak sesuai dengan integritas dan nilai-nilai moral (Hughes, 2018). Dengan rumusan lain, Janet Forsith dalam artikel Philosophy in Business - Why is it relevant....? Menunjukan bahwa konsep dan praktik bisnis yang demikian kompleks perlu diidentifikasi, dipahami, dan diartikulasi untuk menentukan sudut pandang, sikap, dan prilaku secara tepat. Filsafat pada umumnya, dan etika pada khusunya membantu dalam proses tersebut. "Philosophy gives you a tremendous underpinning of all the skills you need to help decisions get made in business..." (Forsith, 2019).

James Griffin dalam buku What Can Philosophy Contribute to Ethics (2015) menunjukkan bahwa meskipun abstrak-normatif, teori-teori etika dari para filsuf merupakan konsep terdepan yang berkontribusi besar bagi pemahaman moral sistematik dalam masyarakat. Pemahaman konseptual filsafati tentang keadilan, kesetaraan, dan hak-hak asasi manusia berkontribusi besar bagi prilaku bisnis dan profesi. Teori-teori moral dari filsafat (etika) tidak hanya membantu dalam mengidentifikasi dan mengambil sikap dan kebijakan praktis bisnis dan profesi secara tepat melainkan juga merealisasikan cita-cira moral ideal manusia.

Dengan demikian pertanyaan pokok yang ingin dijawab oleh artikel ini adalah teori-teori etika mana yang relevan bagi pemahaman terhadap bisnis dan profesi? Pandangan para filsuf utama pendukung teori etika tersebut akan ditampilkan guna melengkapi pemahaman terhadap teoriteori etika tersebut. 


\section{METODE PENELITIAN}

Penelitian kualitatif berupa riset kepustakaan ini menggunakan metode analisis isi (content analisys). Isi setiap materi berupa buku, jurnal, atau artikel yang relevan dengan topik yang berhasil dikumpulkan di telaah, dianalisis, dan disintesis guna membentuk konsep yang lengkap dalam menjawab pertanyaan penelitian.

\section{HASIL DAN PEMBAHASAN}

Etika adalah refleksi kritis tentang apa yang harus dan apa yang tidak boleh dilakukan (Bertens, 2014). Sebagai ilmu etika merupakan cabang filsafat yang mengkaji baik-buruknya tindakan manusia berdasarkan moralitas. Singkatnya, etika adalah filsafat moral. Sementara ajaran moral adalah norma, perintah, atau aturan tentang tindakan mana yang perlu dilakukan dan mana yang perlu dihindari berdasarkan martabat setiap orang sebagai manusia. Berdasarkan pengertian etika dan moralitas tersebut, etika bisnis tidak lain dari penerapan prinsip-prinsip etis (etika) dalam bisnis (Shaw, 1995). Tetapi etika bisnis sejatinya bukan sekedar penerapan nilai-nilai moral dalam bisnis melainkan studi tentang praktik-praktik moral dan imoral dalam bisnis itu sendiri. Singkatnya, etika bisnis adalah studi kritis tentang moralitas bisnis.

Terdapat paling tidak dua cabang pokok etika yang relevan bagi etika bisnis dan profesi yakni etika konsekuensialis atau teleologis dan etika non-konsekuensilais atau deontologis. Yang dimaksud dengan etika konsekuensialis atau teleologis adalah teori etika yang menekankan baik atau buruk suatu tindakan berdasarkan akibat dari tindakan tersebut. Suatu keputusan, kebijakan, atau tindakan secara moral dianggap baik jika keputusan atau tindakan tersebut mendatangkan akibat baik, begitu juga sebaliknya (Brown, 1987). Istilah teleologis sendiri berasal dari kata Yunani telos yang berarti tujuan (goal, end). Yang termasuk dalam teori etika konsekuensialis atau teleologis adalah teori etika utilitarianisme, etika hedonisme, dan etika egoisme. Sementara etika non-kosekuensialis menilai baik atau buruknya suatu putusan, kebijakan, atau tindakan bedasarkan kehendak atau kesadaran orang untuk melakukan apa yang menjadi kewajibannya, berdasarkan nilai, atau berdasarkan prinsip keadilan dan kesetaraan. Teori etika nonkonsekuensialis mencakup teori etika deonologi, etika keutamaan (virtue) dan etika kesetaraan dan keadilan sebagai fairness (Bertens, 2014). Istilah deontologi berasal dari kata Yanani deon yang berarti kewajiban (duty, obligation). Kewajiban moral dianggap self-evident, memiliki nilai instrinsik pada dirinya sendiri, dan tidak membutuhkan justifikasi apa pun. Teori etika yang

\section{Etika Teleologis/Konsekuensialis - Utilitarianisme}

Menurut teori etika teleologis-konsekuensilialis, suatu keputusan atau tindakan dianggap benar secara etis atau bermoral jika keputusan atau tindakan tersebut mendatangkan hasil positif (Brooks \& Dunn, 2011). Yang dimaksud dengan hasil positif antara lain kebahagiaan, kesenangan, kesehatan, kecantikan, pengetahuan, dan sebagainya. Sedangkan hasil negatif mencakup ketidakbahagiaan, kesengsaraan, penyakit, keburukan, dan kebodohan (Bertens, 2014). Dengan demikian penilaian tentang baik/benar (etis) atau buruknya/salah (tidak etis) suatu keputusan atau tindakan didasarkan pada apakah hal baik atau buruk terjadi atau tidak.

Etika teleologi cocok bagi pelaku bisnis yang berorientasi pada hasil karena berfokus pada dampak pengambilan keputusan. Suatu kebijakan, pilihan, keputusan, atau tindakan bisnis dianggap baik atau buruk, diterima atau tidak diterima, berguna atau tidak berguna, dinilai berdasarkan dampak atau konsekunesi dari kebijakan, pilihan, keputusan, atau tindakan tersebut 
(Brooks \& Dunn, 2011). Ketika seorang investor menilai apakah investasi yang dilakukan baik atau buruk, berguna atau tidak, menguntungkan atau tidak, tingkat pengembalian aktualnya (actual return) cepat atau lambat, sesuai atau tidak sesuai dengan harapan investor, di situ sang investor menerapkan pertimbangan etika teleologis. Jika tingkat pengembalian berada di bawah harapan investor, maka investasi tersebut diangap sebagai keputusan investasi yang buruk atau tidak etis; sebaliknya jika tingkat pengembalian aktualnya lebih besar daripada yang diharapkan, maka investasi tersebut dianggap sebagai investasi yang baik atau bermoral. Dengan demikian, jelas bahwa kebaikan atau keburukan suatu keputusan dan tindakan etis tidak terletak pada keputusan atau tindakan pada dirinya sendiri melainkan pada akibat atau konsekuensi dari keputusan tersebut. Dengan demikian kebaikan atau keburukan sebuah investasi dinilai berdasarkan hasil atau konsekuensi dari keputusan investasi (keuangan). Keputusan investasi tersebut dianggap baik, benar, atau etis kalau keputusan tersebut mengakibatkan hasil positif. Sebaliknya, keputusan investasi tersebut dianggap tidak baik, tidak benar, atau tidak etis kalau keputusan tersebut mendatangkan hasil negatif.

Etika teleologis memiliki sejarah yang panjang dalam tradisi filsafat empirisme Inggris. John Locke (1632-1704), Jeremy Bentham (1748-1832), James Mill (1773-1836), dan anaknya John Stuart Mill (1806-1873) merupakan para pendukung utama teori etika teleologis ini.

Etika teleologi memiliki artikulasi yang jelas dalam utilitarianisme. Istilah utilitarianisme berasal dari kata Latin utilis yang berarti "bermanfaat" (Bertens, 2014). Menurut teori utilitariaisme suatu tindakan dianggap baik jika tindakan tersebut membawa manfaat bagi masyarakat secara keseluruhan. Utilitarianisme paling nyata tampak dalam tulisan-tulisan Jeremy Bentham dan John Stuart Mill. Dalam Utilitarianism-nya Mill menulis kredo utilitarianisme yang berbunyi, "Bertindaklah sedemikian rupa sehingga tindakan tersebut mendatangkan jumlah terbesar kebahagiaan dari jumlah terbesar orang yang terkena dampak dari tindakan tersebut!" (The greatest happiness of the greatest number) (Brooks \& Dunn, 2011).

Jelas bahwa utilitarianisme mendefinisikan kebaikan dan kejahatan dalam kaitannya dengan konsekuensi kesenangan dan rasa sakit. Tindakan yang benar secara etis adalah tindakan yang menghasilkan kesenangan terbesar atau jumlah sakit terkecil. Utilitarianisme merupakan teori yang sederhana karena tujuan hidup manusia memang ingin memperoleh kebahagiaan. Kegunaan itu terletak pada kontribusi suatu tindakan bagi kebahagiaan. Semua hal yang mendatangkan kebahagiaan secara etik baik karena cenderung menghasilkan kesenangan atau mengurangi rasa sakit dan penderitaan. Bagi kaum utilitarian, kesenangan dan rasa sakit dapat bersifat fisik maupun mental. Seorang karyawan yang diminta supervisornya untuk menyelesaikan sebuah tugas dan membuat laporan yang berkualitas tinggi tetapi tidak memberikan informasi yang memadai serta rentang waktu yang pendek akan meningkatkan ketegangan dan ketidaknyaman sang karyawan dan dengan demikian tidak berkontribusi bagi kebahagiaan karyawan tersebut. Pengalaman yang baik adalah pengalaman yang menyenangkan karena berkontribusi bagi kebahagiaan secara umum. Dalam kasus ini, menyelesaikan tugas bukanlah hal yang menyenangkan dilihat dari sudut pandang karyawan.

Bagi Mill, kesenangan dan rasa sakit memiliki aspek kuantitatif dan kualitatif. Adalah Jeremy Bentham yang kemudian mengembangkan kalkulus tentang kesenangan dan rasa sakit berdasarkan intensitas, durasi, kepastian, keakraban, kemurnian, dan keluasan. Bagi Mill sifat kesenangan atau penderitaan merupakan sesuatu yang penting. Beberapa kesenangan lebih diinginkan daripada yang lain dan memerlukan usaha untuk mencapainya. Seorang atlit misalnya berlatih tiap hari untuk bertanding di Asian Games. Latihannya sangat menyakitkn tetapi sang 
atlet memfokuskan diri pada hadiah yaitu meraih medali emas. Kesenangan kualitatif berdiri di podium melebihi jalan pajang yang secarta kuantitatif melelahkan demi menjadi juara Asian Games. Begitu juga bagi mahasiswa yang terus belajar secara serius selama 4 tahun yang melelahkan dan memperoleh indeks prestasi cum laude, jaminan kerja yang baik dan gaji yang besar jelas secara kualitatif lebih membanggakan jika dibandingkan dengan keputusan langsung bekerja setamat SMA, menghindari kuliah karena takut mengerjakan banyak tugas, dan stress mengerjakan skripsi.

Etika politik Nicolo Machiavelli yang menegaskan bahwa "tujuan menghalalkan cara" tidak termasuk dalam etika utilitarianisme. Karena meskipun tujuannya untuk menciptakan kemenangan, kemakmuran, keamanan, dan kebanggaan, prinsip tujuan menghalalkan cara memberikan kewenangan tak terbatas kepada Pangeran (Lorenzo Medici) (sekarang: negara) untuk menggunakan cara apa pun (menipu, merampok, membunuh) untuk merebut dan mempertahankan kekuasaan politik. Jelas praktik semacam ini melanggar moralitas dan kemanusiaan kita. Di samping itu, prinsip tujuan menghalalkan cara tidak bisa diterima karena prinsip tersebut mengasumsikan bahwa cara dan tujuan setara secara etika, dan bahwa hanya ada satu cara untuk mencapai tujuan, atau kalau pun ada banyak cara, maka semua cara untuk mencapai tujuan itu setara secara etika. Seorang eksekutif yang memalsukan laporan keuangan untuk meningkatkan laba bersih perusahaan dan dengan demikian ia akan memperoleh bonus, atau seorang eksekutif lain yang memalsukan laporan keuangan untuk mencegah isu kebangkrutan, tetapi menyediakan lapangan perkerjaan bagi karyawan, atau untuk mengembalikan kepercayaan konsumen, kreditor, dan stakeholders. Jelas bahwa kedua eksekutif ini menggunakan cara yang sama (melakukan kecurangan laporan keuangan) untuk mencapai tujuan yang berbeda. Cara yang ditempuh ini secara etika tidak dibenarkan. Untuk eksekutif yang kedua ada alternatif lain yakni ia bisa mencari alternatif pendanaan kembali.

Tetapi harus diingat bahwa teori utilitarianisme mengukur kebahagiaan dan kesenangan atau ketidakbahagiaan dan rasa sakit/penderitaan bukan pada tingkat individu melainkan pada tingkat masyarakat. Artinya yang perlu dipertimbangkan adalah dampak dari suatu keputusan, tetapi yang perlu diukur bukan hanya rasa senang atau sakit dari pembuat keputusan melainkan semua orang yang mungkin terkena oleh keputusan tersebut. Individu seolah-olah menjadi 'penonton' yang tidak memihak karena kebahagiaan yang menjadi standard bagi tindakan bukanlah kebahagiaan pribadi melainkan kebahagiaan semua pihak. Bagi para utilitarian pun tidak bisa menerima bahwa tujuan akhir menghalalkan cara atau sarana. Lagi pula tujuan dasar utilitarianisme adalah kebahagiaan (masa depan) bagai sebanyak mungkin orang (bukan untuk kepentingan pribadi).

Terdapat dua jenis utilitarianisme yakni utilitarianisme perbuatan dan utilitarianisme peraturan. Yang dijelaskan di atas merupakan utilitarianisme perbuatan. Tindakan CEO untuk meminta bonus bagi kepentingan pribadi merupakan contoh bagi utilitarianisme perbuatan. Sementara utilitarianisme peraturan menandaskan bahwa suatu norma, peraturuan, atau hukum baik secara moral jika norma atau peraturan tersebut mendatangkan kebahagiaan sebanyak mungkin orang yang terkena dampak dari peraturan tersebut.

Meskipun berguna dan penting bagi bisnis, teori etika utilitarianisme memiliki beberapa kelemahan mendasar, antara lain:

1. Utilitarianisme mengasumsikan bahwa bahwa kebahagiaan, utilitas, kesenagnan, sakit dan penderitaan bisa diukur. Akuntan misalnya sangat pandai mengukur transaksi ekonomi dalam bentuk uang (rupiah atau dolar) karena uang merupakan standar 
pengukuran yang seragam. Tetapi tidak ada pengukuran umum untuk kebahagiaan, tidak pula kebahagiaan seseorang setara dengan kebahagiaan orang lain. Lagi pula uang bukan perwakilan yang tepat untuk kebahagiaan.

2. Soal distribusi dan intensitas kebahagiaan, prinsip utilitarianisme adalah untuk menghasilkan sebanyak mungkin kebahagiaan dan untuk mendistribusikannya kepada sebanyak mungkin orang. Tetapi dalam praktik, utilitarianisme sepi terhadap prinsip lain seperti keadilan dan kesetaraan. Apakah adil jika mengobarkan kepentingan satu orang demi kepentingan yang lebih besar? Atau apakah adil sebuah keputusan menguntungkan kelompok pembangku kepentingan tertentu dengan mengorbankan kelompok pemangku kepentingan lainnya?

3. Masalah pengukuran lainnya adalah tentang ruang lingkup. Berapa banyak orang yang harus disertakan? Apakah yang mesti diperhitungkan hanyalah kepenitngan investor, masyarakat setempat, global, atau juga pula kepentingan generasi yang akan datang?

4. Utilitarianisme mengabaikan motivasi dan berfokus hanya pada konsekuensi. Pada hal dapat saja terjadi bahwa konsekuensinya sama tetapi motivasinya berbeda. Utilitarianisme dengan demikian tidak cukup menghasilkan keputusan etis yang komprehensif.

\section{Egoisme dan Hedonisme}

Jika utilitarianisme mengukur baik atau buruknya suatu tindakan atau keputusan berdasarkan kegunaan, kepentingan, atau kesenangan jumlah terbesar orang yang terkena oleh suatu tindakan atau keputusan, etika egoisme justru ingin mereduksi tujuan tindakan atau keputusan demi kepentingan diri sendiri tanpa perlu memperhatikan kepentingan orang lain. Seorang manajer yang membuat peraturan tentang system penggajian baru dengan hanya menaikan tunjangan bagi para manager tanpa menyertakan kenaikan gaji para karyawan merupakan contoh praktik etika egoisme dalam bisnis.

Hedonisme merupakan teori etika yang dekat dengan etika egoisme. Karena hedonisme pun memfokuskan diri pada kebahagiaan atau kesenangan pribadi. Adalah Epicurus (341-270 SM), filsuf Yunani kuno pasca trio Yunani (Socrates, Plato, dan Aristoteles) meletakan dasar bagi etika hedonisme ini. Berbeda dengan utilitarianisme yang mengembangkan etika kegunaan dan kebahagiaan pada tingkat sosial-masyarakat, hedonisme merupakan teori etika yang memfokuskan diri pada kebahagiaan dan kesenangan pribadi. Bagi Epicurus dan Epicurean (pengikut Epikurus) 'tujuan hidup manusia adalah untuk memperoleh keamanan, kesenangan, atau kebahagiaan abadi; yaitu suatu kehidupan di mana rasa sakit diterima hanya jika rasa sakit itu menyebabkan kesenangan yang lebih besar, dan kesenangan akan ditolak jika kesenangan itu menyebabkan rasa sakit yang lebih besar' (Brooks \& Dunn, 2011).

Dalam bisnis, keuntungan merupakan tujuan utama. Keuntungan tentu akan semakin tinggi apabila biaya produksi dapat ditekan, upah karyawan tetap, keamanan terjamin, dan penjualan meningkat. Apabila demi memperoleh keuntungan yang semakin besar ongkos produksi tak pernah disesuaikan, upah karyawan tak pernah dinaikan, aspirasi bawah ditekan atas nama stabilitas perusahaan, maka praktik semacam ini merupakan aplikasi etika hedonisme karena hanya untuk memperbesar kebahagiaan pemilik dari pada kepentingan stakeholders secara keseluruhan.

\section{Etika Nonkonsekuensialis - Deontologi}

Etika deontologi menilai etikalitas suatu tindakan atau putusan berdasarkan motivasi pembuat keputusan. Seperti sudah disebutkan di depan, kata deontologi berasal dari kata Yunani deon 
(kewajiban) dan logos (ilmu) (Bertens, 2014). Menurut (prinsip) deontologi, tindakan atau putusan secara etis dibenarkan bukan atas dasar hasil positif atau ditolak bukan atas dasar dampak negatif yang diperoleh melainkan atas dasar motivasi pembuat keputusan atau tindakan tersebut yakni memenuhi apa yang dipahami sebagai kewajibannya. Maka yang menjadi dasar bagi baik buruknya perbutan adalah kewajiban. Kewajiban itu bersifat mutlak.

Filsuf yang pemikirannya selalu dikaitkan dengan etika deontologi adalah Immanuel Kant (17241804). Melalui karyanya Groundwork of the Metaphysics of Moral, Kant menyatakan bahwa satu-satunya yang baik tanpa pengecualian adalah Kehendak Baik; yakni kehendak untuk melakukan apa yang menurut pertimbangan kita (alasan) merupakan kewajiban (tugas) moral kita.

Dengan demikian moralitas suatu tindakan tidak terletak pada dampak atau konsekuensi dari tindakan tersebut melainkan itikad untuk mengikuti atau menaati alasan (pertimbangan) tentang apa yang merupakan tugas atau kewajiban kita yang perlu kita lakukan. Kesediaan atau ketaatan untuk melakukan 'apa yang kita sadari sebagai kewajiban kita' berisfat mutlak, harus, tanpa pengecualian. Bagi Kant, kewajiban merupakan standard yang perlu dipakai untuk menilai etikalitas prilaku. Anda adalah orang yang bertindak dengan benar dan baik atau orang yang bermoral, jika ada mengikuti apa yang merupakan tugas dan kewajiban anda (bukan demi kesenangan melainkan melakukannya melulu demi tugas dan kewajiban tersebut). Motif dari tugas dan kewajibanlah yang memberikan nilai moral bagi tindakan.

Kant memperkenalkan konsep imperatif kategoris (categorical imperative) untuk menjelaskan tuntutan untuk secara mutlak menjalankan apa yang merupakan kewajiban. Prinsip moral, menurut Kant, berlaku tanpa syarat. Prinsip tersebut menuntut bahwa 'anda seharusnya hanya bertindak dengan cara sebagaimana orang lain yang berada dalam situasi yang sama akan bertindak dengan cara yang sama'. Perintah ini bersifat mutlak, tanpa syarat. Maka bagi Kant, suatu perbuatan baik jika ia dilakukan berdasarkan 'imperatif kategoris' (yang mewajibkan kita tanpa syarat apa pun).

Di samping konsep imperatif kategoris untuk menekankan sifat mutlak sebuah tuntutan moral, Kant juga memperkenalkan konsep imperatif praktis (practical imperative) untuk menunjukkan prinsip universalisasi tuntuan moral. Hukum moral bagi Kant berlaku universal tanpa diskriminasi. Prinsip imperatif praktis berbunyi, "Bertindaklah dengan cara yang sama dengan Anda memperlakukan kemanusiaan, baik pada diri anda sendiri atau pada pribadi lainnya..." (Bertens, 2014; Brooks \& Dunn, 2011). Dengan demikian Kant menegaskan bahwa setiap orang harus diperlakukan sama di bawa hukum moral.

Dengan demikian, dalam bisnis, etika deontologi menegaskan tiga hal pokok. Pertama, bahwa motivasi tindakan atau putusan bisnis bukanlah demi sesuatu yang lain di luar tujuan moral bisnis melainkan justru melakukan apa yang merupakan kewajiban moral bisnis itu sendiri. Yang termasuk dalam kewajiban moral bisnis, misalnya untuk membuka lapangan pekerjaan, meningkatkan kesejahteraan masyarakat, mendayagunakan sumber daya agar produktif, merealisasikan bakat dan potensi tenaga kerja, dan sebagainya. Kedua, bahwa setiap orang dan stakeholders dalam bisnis harus diperlakukan setara, tanpa diskriminasi. Orang atau stakeholders lain harus diperlakukan tidak sekedar sarana melainkan sebagai tujuan akhir dalam diri mereka sendiri (Bertens, 2014). Seorang akuntan profesional misalnya, secara moral tidak dibenarkan memanfaatkan mahasiswa magang untuk memeriksa laporan keuangan kliennya karena digaji lebih kecil dari keuntungan yang ia peroleh dari kliennya. Hubungan antara majikan dan 
karyawan, antara pimpinan dan bawahan harus didasarkan pada rasa hormat, otonom, kreatif, dan bermartabat dan bukan atas dasar kekuasaan, manipulasi, intrik, dan merendahkan. Dalam bisnis, setiap orang atau stakeholders, tidak hanya diperlakukan sebagai sarana melainkan terutama sebagai tujuan akhir sekaligus. Dan ketiga, kewajiban untuk bertindak etis, tidak hanya berlaku bagi diri sendiri melainkan juga bagi orang lain.

Meskipun ideal, teori etika deontologi memiliki dua kelemahan mendasar. Pertama, bahwa prinsip imperatif kategoris tidak memberikan panduan yang jelas untuk menentukan mana yang benar dan mana yang salah jika dua atau lebih hukum moral mengalami konflik dan hanya satu yang dapat diikuti. Hukum moral mana yang perlu diikuti? Utilitarianisme jelas mnyatakan bahwa kita mesti mengikuti yang paling mendatangkan konsekuensi postiif. Sementara deontologi melihat konsekuensi tidak relevan. Satu-satunya hal yang penting adalah niat pembuat keputusan. Kedua, imperif kategoris menetapkan standard yang sangat tinggi. Bagi banyak orang itu adalah etika yang sulit diikuti. Ada banyak contoh dimana orang tidak diperlakukan dengan hormat dan bermartabat, dimana mereka hanya dilihat sebagai alat dalam siklus produksi dan akan digunakan, tetapi kemudian dibuang karena kegunaannya hilang. Banyak perusahaan mempekerjakan (memperalat) anak-anak dibawa umur dengan upah rendah. Tidak sedikit perusahaan yang mempekerjakan pekerja kontrak untuk menghindari tuntuan untuk memberikan fasilitas ketenagakerjaan. Pandangan Kant mengandaikan bahwa kita semua merupakan bagian dari komunitas moral yang menempatkan tugas dan kewajiban di atas kebahagiaan dan kesejahteraan ekonomi. Suatu standar moral yang sangat ideal, karena dapat saja ketika orang mengikuti kewajiban dapat mengakibatkan konsekuensi yang merugikan.

\section{Etika Keutamaan atau Kebajikan}

Etika kebajikan mengambil inisiatif dari filsuf Yunani Aristoteles (384-322). Dalam buku The Nicomachean Ethics, Aristoteles menegaskan bahwa tujuan hidup manusia adalah kebahagiaan (eudaimonia). Kebahagiaan yang dimaksud bukan dalam arti hedonistik (kesenangan) melainkan suatu kegiatan jiwa yang merasa bahagian karena memenuhi tujuan hidup yang mulia dengan hidup sesuai alasan; bertindak secara sukarela (bebas). Maka etika keutamaan atau kebajikan memfokuskan moralitas pada karakter moral pembuat keputusan. Karakter moral dapat dibentuk melalui pendidikan moral.

Dalam bisnis, etika keutamaan penting karena pada akhirnya, moralitas binsis bergantung pada karakter moral pribadi insan bisnis itu sendiri. Perusahaan yang secara moral baik diwujudkan oleh kualitas moral semua orang yang terlibat di dalamnya. Moralitas perusahaan tidak lain dari moralitas individu-individu yang ada di dalamnya. Dengan demikian seorang eksekutif tidak bisa pada suatu kesempatan mengatakan bahwa ia bertindak atas nama perusahaan dan di kesempatan terpisah ia bertindak atas nama pribadi. Sebagai pribadi yang utuh, stabil dan konsisten ia adalah seorang pribadi bermoral. Karakter moral selalu melekat pada sang eksekutif tersebut (Bertens, 2014).

Kelemahan etika kebajikan adalah bahwa nilai-nilai kebajikan seperti integritas, jujur, terhormat, konsisten dengan prinsip dan tidak mengorbankan nilai inti, dalam praktik sering sulit diwujudkan. Etika bisnis sering dianggap oxymoron; suatu keinginan suci yang sulit untuk direalisasikan.

\section{Etika Kesetaraan dan Keadilan sebagai kewajaran (fairness)}

Etika keadilan bisa dianggap sebagai penengah antara etika utilitarianisme dan etika deontologi. Karena etika keadilan menekankan manfaat dan beban berdasarkan alasan yang rasional. 
Filsuf Inggris David Hume (1711-1776) mengatakan bahwa keadilan merupakan sesuatu yang penting karena: orang tidak selalu bermanfaat dan terdapat sumber daya yang langka. Hume percaya bahwa masyarakat terbentuk melalui kepentingan pribadi. Karena manusia tidak bisa hidup sendiri, ia memerlukan kerja sama bagi keberlangsungan hidup dan kesejahteraan bersama. Tetapi karena sumber daya terbatas, dan faktanya beberapa orang mendapatkan keuntungan dengan merugikan orang lain, maka perlu ada mekanisme untuk pembagian manfaat dan beban bagi masyarakat secara adil. Maka keadilan merupakan mekanismenya. Orang harus memiliki klaim yang sah atas sumber daya yang langkah dan dapat secara rasional menjelaskan dan membenarkan klaim mereka atas sumber daya tersebut. Itulah prinsip dasar keadilan: mengalokasikan manfaat dan beban dengan alasan yang rasional.

Terdapat dua macam keadilan yakni keadilan prosedural dan keadilan distributif. Keadilan prosedural menuntut agar semua orang diperlakukan secara sama; tidak ada preferensi dan diskriminasi berdasarkan kelompok, suku, agama, ras, dan status sosial. Dalam organisasi bisnis, keadilan prosedural tampak pada prosedur operasi standar yang sama dan konsisten bagi semua karyawan. Sementara keadilan distributif atau keadilan proporsional (Bertens, 2014) menunut perlakuan yang sama untuk hal yang setara, dan untuk hal yang tidak setara harus diperlakukan berbeda. Misalnya, upah yang sama untuk pekerjaan yang sama, lepas dari perbedaan gender. Sebaliknya apabila mereka tidak benar-benar sama, maka mereka tidak harus diperlakukan sama. Misalnya perbedaan upah berdasarkan pengalaman, pangkat, pendidikan, dan tanggung jawab.

\section{Keadilan sebagai kewajaran (fairness).}

Adalah John Rawls (1921-2002) yang mengembangkan konsep keadilan sebagai kewajaran atau fairness. Dalam buku Theory of Justice, Rawls mengatakan bahwa setiap orang selalu memiliki kepentingan pribadi dan tak seorang pun bisa memperoleh semua hal yang mereka inginkan. Oleh karena itu ia perlu bekerja sama dalam masyarakat untuk mencapai keuntungan bersama. Dengan demikian perlu ada usaha untuk menyeimbangkan konflik kepentingan; perlu ada upaya menyeimbangkan manfaat atau keuntungan yang lebih besar dari pada beban yang mesti mereka pikul. Prinsip yang dipakai untuk menentukan alokasi yang merata adalah prinsip-prinsip keadilan. Keadilan sebagai kesetaraan berarti bahwa apa pun yang mereka setujui pada keadaan awal akan dianggap adil oleh semua.

Rawls memperkenalkan dua macam prinsip keadilan yang menurut Rawls pasti akan dipilih oleh orang yang bebas dan rasional di bawah selubung ketidakpedulian (veil of ignorance) (tidak tahu dan tidak peduli terhadap segala status, kelas, atau potensi yang dimiliki). Prinsip pertama adalah prinsip perbedaan, dan prinsip kedua adalah prinsip persamaan. Prinsip perbedaan menegaskan bahwa ketidaksetaraan sosial dan ekonomi harus bermanfaat bagi anggota masyarakat termiskin. Sementara prinsip persamaan menegaskan bahwa akses ke ketidaksetaraan harus terbuka bagi semua orang. Dengan demikian prinsip perbedan mengakui bahwa sumbangan alam tidak mencukupi (tidak merata). Ada yang lahir dari alam yang kaya raya sementara yang lain sangat miskin. Ada orang dengan bakat yang luar biasa sementara yang lain tidak. Ini merupakan ketidakadilan. Tetapi berdasarkan prinsip keadilan sebagai kesetaraan, apa yang benar dan jujur adalah bahwa setiap orang harus diuntungkan dengan adanya ketidaksetaraan sosial dan ekonomi. Bagi Rawls, difusi keberuntungan harus menguntungkan semua orang; terbuka bagi semua orang. Maka ketimpangan diakui, tetapi ketimpangan tersebut juga diterapkan untuk kebaikan semua. Misalnya ketentuan tentang gaji tertinggi dan gaji terendah, menerapkan prinsip perbedaan. Gaji tertinggi bagi para eksekutif sebuah perusahaan hanya dapat dibenarkan (adil) jika kesenjangan tersebut lebih banyak membantu karyawan dengan bayaran terendah di 
perusahaan. Dan ini dianggap Rawls sebagai sesuatu yang wajar karena menciptakan kesetaraan karena menguntungkan semua pihak.

\section{KESIMPULAN DAN SARAN}

Sebagai ilmu etika adalah cabang filsafat yang mempertimbangakan secara kritis tindakan mana yang baik atau tindakan mana yang buruk berdasarkan ajaran moral. Sementara etika bisnis bukan sekedar penerapan prinsip-prinsip etika dalam bisnis melainkan studi kritis terhadap praktik bisnis dari perspektif moral. Terdapat paling tidak dua teori utama etika yang relevan bagi etika bisnis. Pertama teori etika konsekuensialis atau teleologis. Kedua, teori etika nonkonsekuensilis. Teori etika konsekuensialis menilai moralitas tindakan atau keputusan bisnis berdasarakan tujuan, kegunaan, atau dampak positif yang diperoleh dari tindakan atau keputusan tersebut. Sementara etika nonkonsekuensialis memfokuskan moralitas tidakan atau putusan bisnis pada kewajiban untuk melakukan apa yang merupakan kewajiban, pada motivasi dan karakter moral si pelaku tindakan, serta pada prinsip keadilan.

Studi dari perspektif filsafati (etika) ini akan jauh lebih kaya dan komprehensif jika dapat dilakukan lebih jauh studi tentang etika bisnis dari perspektif agama-agama. Beberapa usaha ke arah ini sudah dilakukan tetapi masih perlu diperdalam lebih jauh agar menghasilkan insight yang berguna bagi pemahaman terhadap tindakan dan keputusan bisnis.

\section{REFERENSI}

Agoes, S. \& Ardana, CI. (2017). Etika Bisnis dan Profesi: Tantangan Membangun Manusia Seutuhnya. Salemba Empat, Jakarta.

Bertens, K. (2013). Pengantar Etika Bisnis. Kanisius, Jogyakarta.

Brooks, LJ. \& Dunn, P. (2011). Etika Bisnis \& Profesi untuk Direktur, Eksekutif, dan Akuntan, buku 1, diterjemahkan dalam Bahasa Indonesia oleh Kanti Pertiwi dari judul asli Business \& Professional Ethics, Salemba Empat, Jakarta.

Brooks, LJ. \& Dunn, P. (2012). Etika Bisnis \& Profesi untuk Direktur, Eksekutif, dan Akuntan, buku 2, diterjemahkan dalam Bahasa Indonesia oleh Kanti Pertiwi, dari judul asli Business \& Professional Ethics. Salemaba Empat, Jakarta.

De George, R. (2015). "The Relevance of Philosophy to Business Ethics: A Response to Rorty's 'Is Philosophy Relevant to Applied Ethics?'”. Published Online, 23 Januari 2015. https://doi.org/10.5840/beq200616328 dari artikel asli dalam Business Ethics Quarterly, Vol. 16. Issue 3, Juli 2006, 381-389.

Duska, R. (1993). "Aristotle: A Pre-Modern Post-Modern? Implications for Business Ethics". Business Ethics Quarterly, 3,(3), 227-250.

Brown, N. (1987). "Teleogoligal or Dentology?". Irish Theological Quarterly, Vol. 53, Issue 1, 36-51. Akses online 6 Maret 2019 di https://doi.org/10.1177/002114008705300103

Garret, T. M. (1970). Business Ethics, New Delhi, Times of India Press, 1970, hlm. 4

Griffin, J. (2015). What Can Philosophy Contribute to Ethics. Oxford University Press. Oxford.

Hugges, J. (2018). "Four Reasons Why Philosophy Is Relevant As Ever", online at http://www.bachelorstudies.com, diunduh 2 Maret 2019.

Keraf, S. (). Pengatar Etika Bisnis. Kanisius, Jogyakarta.

Shaw, W., \& Barry, V. (1995). Moral Issues in Business. Wadsworth Publishing Company, Belmont - California.

Shaw, W. (2005). Business Ethics (5th ed.). Thomson Wadsworth, Belmont, CA.

Yosephus, LS. (2010). Etika Bisnis: Pendekatan Filsafat Moral terhadap Perilaku Pebisnis Kontemporer. Obor Indonesia, Jakarta. 